\title{
Factors Influencing Farmer's Decision-Making Behavior on Rural Construction Land Transformation
}

\author{
Xuesong Sun, Zaisheng Zhang and Yiye Zhang * \\ College of Management and Economics, Tianjin University, Tianjin 300072, China; sunxs@tju.edu.cn (X.S.); \\ zhangzs@tju.edu.cn (Z.Z.) \\ * Correspondence: yiyezhang@tju.edu.cn; Tel.: +86-392-082-5843
}

Received: 29 September 2018; Accepted: 14 November 2018; Published: 19 November 2018

\begin{abstract}
In order to protect cultivated land and balance farmers' needs and shortage of land, the Chinese government introduced policies to rearrange land use in rural areas. However, many problems, such as unused rural construction land and illegally occupied land, have occurred through implementing land use policies. Rural construction land transformation has been promoted to solve these problems. This transformation was designed to let farmers voluntarily transforming their idle rural construction land. Then, local government could rearrange village layout for developing cultivation, industry and green space. Therefore, in order to analyze the factors that influenced farmers' decision-making behavior in rural construction land transformation, household surveys were conducted in four typical villages in Jizhou District. After using the Probit model to analyze the data, the results indicated that the willingness to settle in the city, the mode of housing resettlement, the mode of compensation, the rationality of the measurement standards, and the annual total household income positively affected the willingness of farmers to transform their rural construction land. The strong willingness to settle in the city dominated the other factors. Moreover, the age and amount of construction land, the method of construction land acquisition, and the amount of cultivated land negatively affected the decision-making behavior during the transformation of rural construction land. Based on the influencing factors, policy suggestions are proposed from the perspectives of establishing an orderly transformation mechanism, implementing priority transformation, and providing compensation for transforming rural construction land.
\end{abstract}

Keywords: land transformation; rural households; willingness and behaviors; China

\section{Introduction}

The current rural construction land use system in China is collectively owned and used by rural households [1]. This system has undergone continuous adjustment and improvement since the 1960s and eventually became a relatively complete institutional arrangement in the late 1980s [1]. It is a process through which urban residences, farmers from other villages, and returned overseas Chinese have lost the usage rights to the rural construction land that nowadays only the farmers from their own collective economic organization (normally from their own village) can apply for [2,3]. Present reform of rural construction land consolidation began in the 2000s, during which the Chinese government gradually strengthened the relevant policies for the registration of affirmative rights of rural collective land, and improved the functions of rural construction land [4]. According to the evolution of the ownership and characteristics of rural construction land, the institutional change in rural construction land can be divided into five stages (Table 1) [3,5-9]. 
Table 1. Formation stages and main features of rural construction land in China.

\begin{tabular}{cl}
\hline Formation Stage & \multicolumn{1}{c}{ Main Features } \\
\hline $\begin{array}{c}\text { 1949-1956 } \\
\begin{array}{c}\text { Period of rural land reform and } \\
\text { elementary cultivated } \\
\text { producers' cooperative }\end{array}\end{array}$ & $\begin{array}{l}\text { House and construction land are issued with cultivated land (mainly cultivated } \\
\text { land), to form clear property rights and boundaries. Rural land, including } \\
\text { construction land, is free to operate, rent, and trade. Farmers have the } \\
\text { ownership of the house and the construction land. }\end{array}$ \\
\hline $\begin{array}{c}\text { 1956-1962 } \\
\text { Period of advanced }\end{array}$ & $\begin{array}{l}\text { In the period of cultivated cooperation, cultivated land, livestock, cultivated } \\
\text { implements, and labor are fixed in the community, not including burial } \\
\text { grounds and construction land, fixes force. Construction land is the private } \\
\text { property of the members in the community. }\end{array}$ \\
\hline $\begin{array}{c}\text { 1962-1981 } \\
\text { 1981-2008 }\end{array}$ & $\begin{array}{l}\text { Construction land is owned by the collective, and is forbidden to be rented or } \\
\text { traded. Members in the community own the houses, and they have the right to } \\
\text { trade or rent the houses. As a social welfare, rural construction land is free } \\
\text { to access. }\end{array}$ \\
\hline $\begin{array}{c}\text { Period of strengthening policy and } \\
\text { management system of rural } \\
\text { construction land }\end{array}$ & $\begin{array}{l}\text { This period clarifies the policy system of use, approval, and transform of rural } \\
\text { construction land. Rural construction land experienced a process of obtained } \\
\text { free of charge, then was used for compensation, and finally returned to free of } \\
\text { charge in this period. }\end{array}$ \\
\hline $\begin{array}{c}\text { 2008-now } \\
\text { Period of reform rural construction } \\
\text { land use system }\end{array}$ & $\begin{array}{l}\text { In this period, the Chinese government has launched registration and } \\
\text { certification work of housing and construction land integration, meanwhile } \\
\text { cautiously promoted the pilot work on mortgages and guarantees transfer of } \\
\text { farmers' housing rights. Pilot works are encouraged to adapt to local } \\
\text { conditions. The government also focused on issues such as } \\
\text { conservation-intensive utilization of construction land, acquisition of voluntary } \\
\text { compensation, and extension of the examination and approval system. }\end{array}$ \\
\hline
\end{tabular}

With certain public welfare characteristics, such as use without any rent or purchasing cost and one rural construction land for one family, the Chinese rural construction land use system played a historical role for the stability of rural society and the development of creating prosperous and contented life for the farmers [10]. However, with the growth of population and economic development, especially the rapid development of industrialization and urbanization, the demand for urban construction land is increasing [11]. In addition, the blind and unordered expansion of rural construction land and the emergence of rough and inefficient use of rural land resources resulted in a "two-way squeeze of cultivated land". This eventually led to the imbalance of the rural construction land use system $[7,12]$. Therefore, the present rural construction land use system has been unable to adapt to social development and has intensified several social conflicts to some extent.

The current situation is that due to the inappropriate management of rural land, there exist problems that one household had multiple construction lands. Some of the construction lands are not used, while some were not legally approved. This disorderly expansion of rural construction land results in shortages of collective industrial and business land, and destruction of cultivated land. Thus, transforming idle rural construction land may not be a risk for rural development. It may not only expand the area of cultivated land to increase grain production, but also optimize rural land structure to develop rural industry. After 40 years of rapid development in rural land management, due to huge differences in infrastructure and development stages in different regions, the local governments began to classify and implement the reform of rural construction land [13-16]. For the purpose of improving rural construction land consolidation, the Chinese government launched 15 pilot areas to reform rural construction land use in 2015. For example, Chongqing established a rural land exchange platform to promote transactions between land and "land tickets" (a certificate issued by the land administration that reflects the conversion of land) [17]. Through this platform, farmers could obtain land tickets and move to commercial residence buildings in the city after idle construction land was restored and accepted by local government [18]. This method could not only alleviate the current urban construction land shortage, but also strengthen the intensive use of rural construction land [19]. In Jiaxing, for the farmers who are willing to leave their idle rural construction land and settle in the city, a unified collection and redevelopment of the withdrawal land will be carried out [20]. Those farmers could 
gain affordable housing in the city with their rural construction land transformation certificate [21]. For the farmers who accept the rural construction land consolidation policy and transform their idle construction land in Chengdu, they receive a preferential housing purchase subsidy and social insurance in a centralized residence area, an employment subsidy for a job transfer, and a subsidy for transforming their construction land based on the corresponding area [16,22].

After transforming the rural construction land, the local government will rearrange the land to develop collective internal circulation, infrastructure, and public service facilities, or convert the land for cultivation and green space. The village layout can be rearranged and optimized. In specific, first, the local government must to set up collective internal circulation. Members in the village could apply for or rent the land if they are over 18 years old and have not had rural construction land before. Second, the transformed land could be transformed into cultivated land. This change would not only upgrade the scale and layout of cultivated land, but also increase grain production. Third, local governments could integrate rural land. Specifically, infrastructure, commercial land, and public service facilities could be rearranged to optimize the land use structure and layout, so economic construction could be sustainably developed. Moreover, ecological land area and green space will increase. Hence, rural construction land transformation could contribute to ecological sustainability.

In order to promote rural construction land consolidation, this study presents theories and rural studies regarding human behavior and rural construction land consolidation. Along with considering the connections between external environment and personal characteristics, the aim of this study was to evaluate the influencing factors of farmers' willingness to transform their unused rural construction land. In addition, policy suggestions based on the analysis results are presented.

\section{Methodology and Data}

\subsection{Study Area}

As one of the 15 pilot areas, the reform of construction land consolidation in Jizhou District, Tianjin, started in 2015, implementing transformation with compensation using multiple methods, consisting of establishing a collective internal circulation mechanism of rural construction land and reforming the management system for the approval of rural construction land. Relevant policies such as the "Detailed rules for reform rural construction land consolidation system in Jizhou District" have been issued and implemented, which achieved certain goals. Therefore, Jizhou District was selected as the study area to discuss what factors may affect farmers' willingness to transform their idle rural construction land.

Considering possible influencing factors such as location, environment, and economics, this survey was conducted in four villages in Jizhou District: Tuanshanzi, Xiaochuanfangyu, Chengjiazhuang, and Xitaihe. Jizhou District is located in the north of Tianjin, China (Figure 1). As mountain, mid-levels, and plains are the three types of land in Jizhou District, the geographical characteristics of these four villages are representative of the district, including plain, mountain, mid-levels (reservoir area), and surrounding town areas. Due to the differences in geographical location, obvious differences exist in the economic structure, which made them ideal as first pilot villages for rural construction land consolidation reform. Among these four villages, Tuanshanzi, with a population of 602 , is located in the mountain area in the northern part of Jizhou District, with beautiful scenery near the village. However, because of the layout of construction buildings and roads and poor environment, the development of the tourism industry has been seriously constrained, and the income of farmers' lags behind those of the other surrounding villages. Xiaochuanfangyu is one of the most famous tourism villages in Jizhou District, with a reservoir in the surrounding area. This village runs businesses and tourism services as its main source of income. Chengjiazhuang is located in the center of Shangcang in the southern part of Jizhou District. This village has a population of 1485, and the main source of economy is industrial management and collective land contracting. It also has the strongest economy amongst the four villages. Xitaihe is a typical plains village. Agriculture is the main sector of the village economy. 
The economic strength is the weakest amongst the four villages. Because of the differences, these four villages comprehensively represent the current rural development situation in Jizhou District.

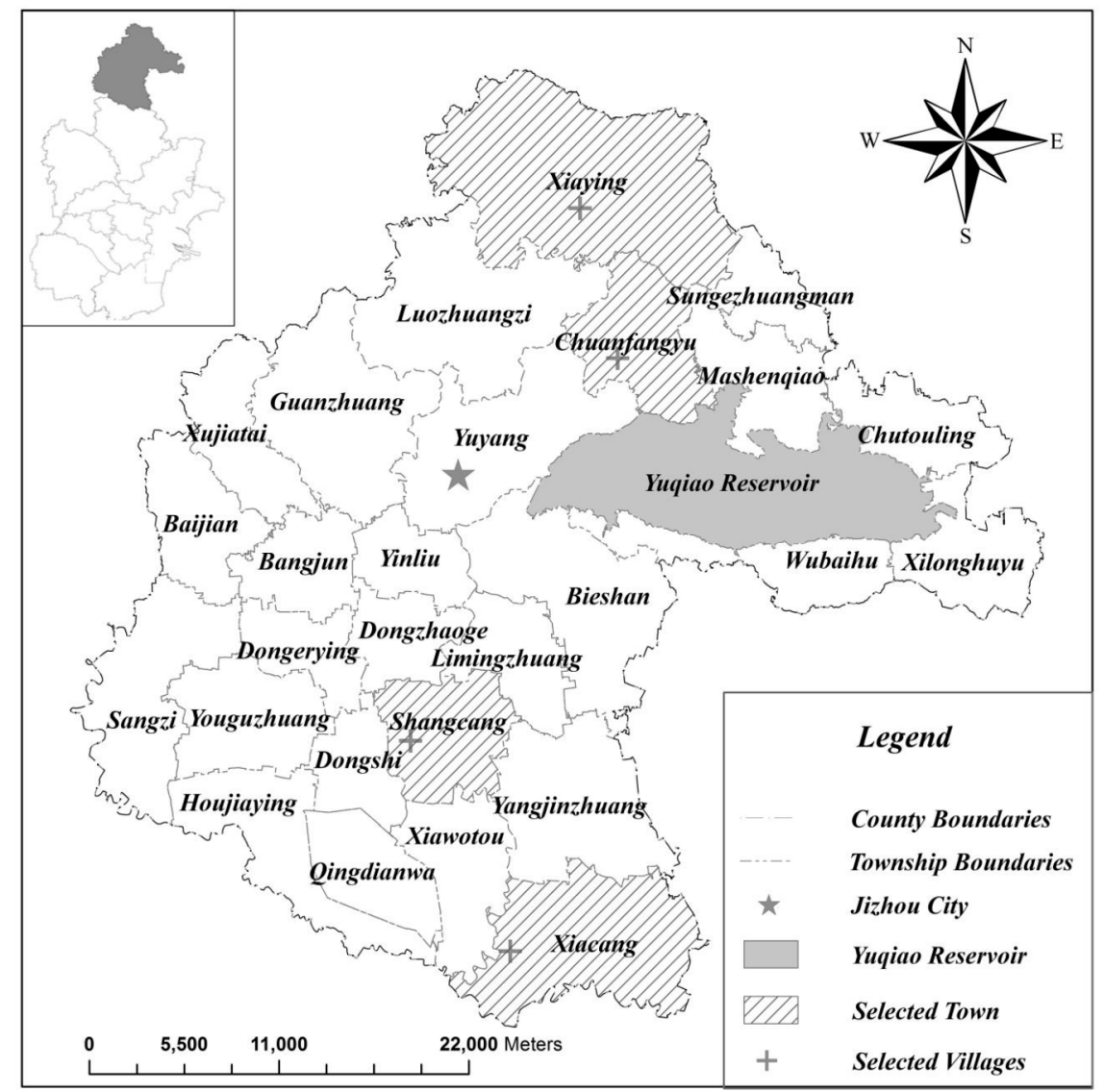

Figure 1. Study area.

\subsection{Theoretical Analysis of Decision-Making for Rural Construction Land Transformation}

From the perspective of behavioral economics, during the decision-making for rural construction land transformation, farmers are assumed to be rational, while pursuing the maximization of self-interest [23]. However, the specific environment may also influence the decision makers, so that they cannot be completely rational. The behavior of decision-makers is affected by their cognitive level. The cognitive level is affected by factors such as personal characteristics, external family characteristics, livelihood resources and environment, and policy information. It is a dynamically changing psychological process from cognition to decision-making that affects the behavior of decision-makers. Therefore, the theoretical model for the limited rational decision-making of rural construction land transformation is formulated as follows:

$$
D_{t}=F\left(C_{t}\right), C_{t}(P e, F a, C l, P o)=a P e_{t}+b F a_{t}+c C l_{t}+d P o_{t}+\varepsilon
$$

where $D$ is the farmer's bounded rational decision function; $C$ is the farmer's cognitive level; $P e$ is the farmer's personal characteristics, including psychological factors such as age, education level, and willingness to move to the city; $F a$ is the family characteristics, including the household population, quantity of labor force, family economic status, and quantity of cultivated land; $\mathrm{Cl}$ is the livelihood resources and environment, including the amount of construction land, acquisition methods, and acquisition time, status of construction land; $P o$ indicates policy information, including compensation methods, resettlement mode, and compensation measurement rationality; $\varepsilon$ is the disturbance term that refers to the uncertainty factors; $a, b, c$, and $d$ are the impact coefficients; and $t$ is the time variable. 
From the theoretical model, the rural construction land transformation is affected by many factors: the age of the householder, cultural level, and psychological factors, as well as being influenced by external environmental factors such as family, livelihood resources, and policy information. Differences exist in rural construction land transformation through limited rational decision analysis and comparison under the combined effects of multiple factors (Figure 2).

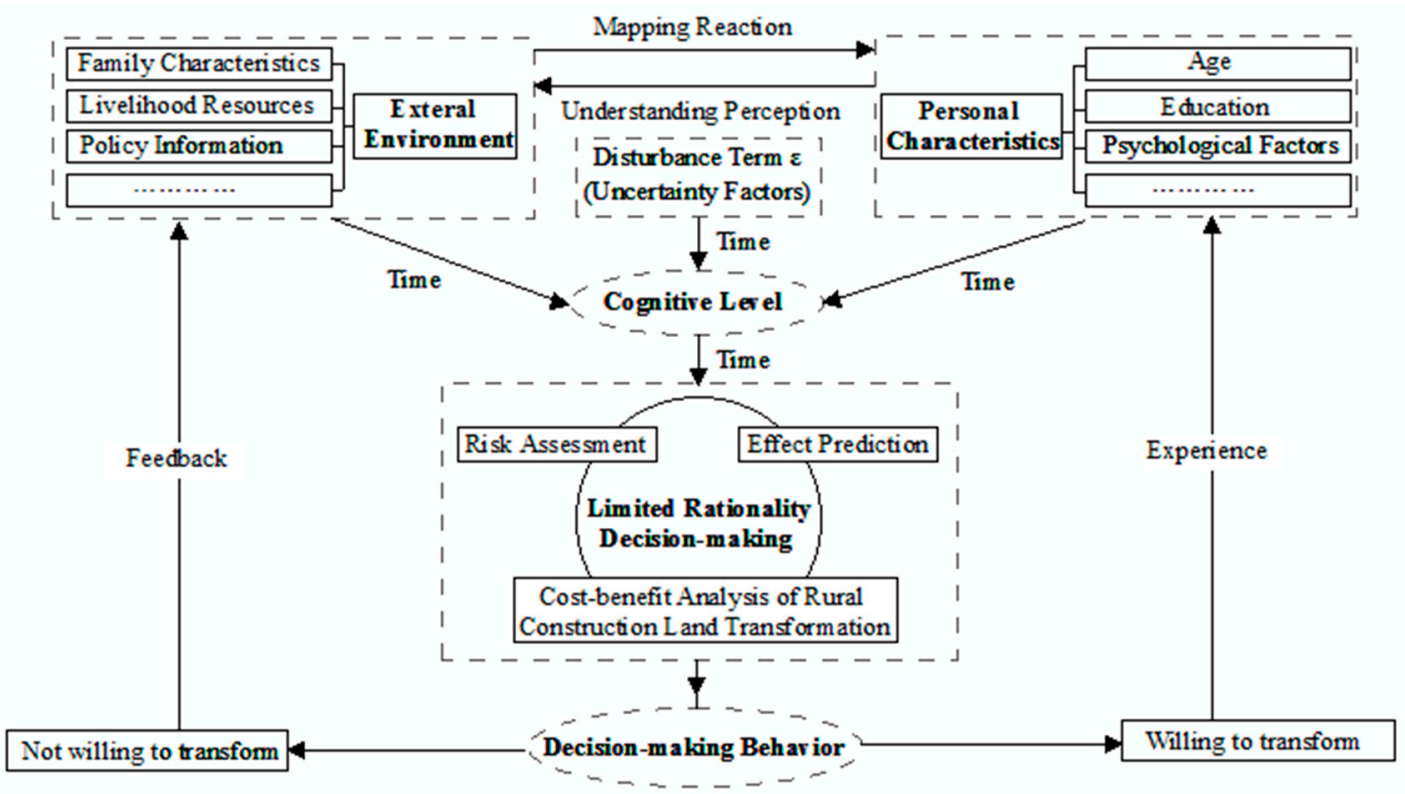

Figure 2. Decision-making behavior of farmer construction land transformation.

\subsection{Samples and Method}

\subsubsection{Variable Design}

Previous studies explored the factors influencing farmers' willingness to transfer their idle construction land, consisting of individual characteristics, family characteristics, current situation of construction land, and construction land consolidation policy. For example, Yang [24] and Wang et al. [25] proposed that individual characteristics include age and education, in which the evidence indicated that the higher the level of education, the higher the level of willingness of the farmers' land transformation decision-making behavior. However, different scholars have proven that age positively or negatively influences the willingness of farmers to transform their rural construction land [25-28]. For family characteristics factors, family income and the number of elderly people in the family positively influence the willingness of a farmer to transform their rural construction land, whereas the number of children in the family negatively influences that willingness [28-30]. For the compensation method factors, studies have focused on the impact of reasonable compensation, such as monetary compensation and preferential housing purchase in cities, on farmers' decision-making behavior for their rural construction land transformation. Yang [25] proved that the government provision of compensation positively influences the willingness of farmers to transform rural construction land [25]. Among the studies related to the relationship between housing condition and rural construction land transformation behavior, it has been proposed that the construction land area and the residence condition on the that land negatively influence the willingness of a farmer to transform rural construction land [31,32].

As such, the decision-making process for rural construction land transformation could be affected by factors such as education, family characteristics, status of construction land, and their understanding of policies $[25,33,34]$. However, the key factor for achieving rural construction land consolidation is to allow farmers transfer their idle construction land voluntarily. Whether farmers are willing to make the transformation is mainly due to the bounded rationality selection mechanism [28,35-37]. Specifically, 
under certain external constraints, such as the attachment to rural construction land, the farmers may compare their expected income-cost before and after the transformation to seek a satisfactory solution. The newness of the rural construction land may also affect farmers' decision-making behavior as a financial loss. Therefore, three variables were added in this study to measure the attachment for rural construction land, consisting of acquisition method of rural construction land (approval, inheritance, or purchase), acquisition time of rural construction land, and newness of rural construction land.

In the early stage of the pilot construction land consolidation reform in Jizhou District, the local government conducted a household survey in the four study villages. Obtaining support from the local government, this study participates in the survey in Tuanshanzi to pretest whether respondents could understand the questions and whether the proposed variables fully explain the factors influencing a farmer's decision-making behavior on rural construction land transformation. After one-on-one communication with representatives from each household in Tuanshanzi, it can be found that despite the variables mentioned in a previous study [24-32], factors such as willingness to settle in the city, resident condition, and amount of cultivated land may also influence the decision-making behavior of farmers to transform their rural construction land. Moreover, through communication, it can be found that farmers prefer to transform their rural construction land into money or receive resettlement housing. Since most farmers' main income is crop income on cultivated land, after transforming rural construction land and settling in the city, there is no guarantee of housing and income sources in the short term. Thus, they prefer financial compensation and housing compensation once they decide to transform their rural construction land. Therefore, based on the above considerations, personal characteristics, family characteristics, construction land conditions, compensation method, and willingness to transfer to the city were selected as variables.

\subsubsection{Samples}

A household survey was conducted to collect samples. In the process of collecting questionnaires, each household from four villages sent a representative to fill in the questionnaire. In order to ensure the accuracy of the information and the integrity of the questionnaire, oral explanations were provided to the respondents who could not read or did not understand the question. A total of 750 questionnaires were sent out, and 659 questionnaires were valid, with an effective rate of $87.87 \%$. Since the younger generation are more likely to work in the cities, the age in the sample was mainly over 45 years old, accounting for $85.43 \%$ of the total sample size. Education level was mainly secondary and primary school, accounting for $71.17 \%$ and $25.34 \%$, respectively. The number of family members ranged from 2 to 5 , and the distribution was relatively uniform. The most common family size was 2 among the samples, accounting for $45.22 \%$ of the total. More than 50,000 yuan per year in annual income was the most common, accounting for $56.45 \%$ of the respondents. The annual total household expenditure ranged from 10,000 yuan to 50,000 yuan, accounting for $70.72 \%$ of the respondents. Most households only had one piece of construction land and less than 0.3335 hectares cultivated land, accounting for $87.56 \%$ and $59.48 \%$, respectively. Apart from legal approval, inheritance and purchase of rural construction land accounted for $5.16 \%$ and $1.21 \%$, respectively. Length of acquisition time was mainly concentrated around 30-40 years, accounting for $61.31 \%$, among which most of the older residences on the construction land had not renovated, accounting for $71.47 \%$. Among all the samples, $69.95 \%$ of the farmers were willing to move to the city, and $30.05 \%$ did not want to settle in the city. Of the respondents, $38.39 \%$ were willing to leave the rural construction land on the premise of reasonable compensation, whereas $61.61 \%$ did not want to make the transformation. This implies that the famers who move to the city may still want to keep their rural construction land (Table 2). 
Table 2. Sample basic characteristics.

\begin{tabular}{|c|c|c|c|c|c|c|c|}
\hline Variable & Options & Number & Proportion & Variables & Options & Number & Proportion \\
\hline \multirow{4}{*}{ Age } & $\leq 30$ & 17 & $2.58 \%$ & \multirow{4}{*}{$\begin{array}{l}\text { Annual household } \\
\text { expenditure }\end{array}$} & $<10,000$ yuan & 74 & $11.23 \%$ \\
\hline & $30-45$ & 79 & $11.99 \%$ & & $10,000-30,000$ yuan & 256 & $38.85 \%$ \\
\hline & $45-60$ & 318 & $48.25 \%$ & & $30,000 \sim 50,000$ yuan & 210 & $31.87 \%$ \\
\hline & $\geq 60$ & 245 & $37.18 \%$ & & $>50,000$ yuan & 119 & $18.06 \%$ \\
\hline \multirow{4}{*}{ Education } & Primary school and below & 167 & $25.34 \%$ & \multirow{3}{*}{ Size of cultivated land } & No cultivated land & 10 & $1.52 \%$ \\
\hline & Secondary school & 469 & $71.17 \%$ & & $<0.3335$ hectares $(5 \mathrm{mu})$ & 392 & $59.48 \%$ \\
\hline & College & 14 & $2.12 \%$ & & $\geq 0.3335$ hectares $(5 \mathrm{mu})$ & 257 & $39.00 \%$ \\
\hline & Bachelor degree and above & 9 & $1.37 \%$ & \multirow{3}{*}{ Pieces of construction land } & 1 & 577 & $87.56 \%$ \\
\hline \multirow{4}{*}{ Family population } & $\leq 2$ & 172 & $26.10 \%$ & & 2 & 75 & $11.38 \%$ \\
\hline & 3 & 178 & $27.01 \%$ & & $\geq 3$ & 7 & $1.06 \%$ \\
\hline & 4 & 146 & $22.15 \%$ & \multirow{3}{*}{$\begin{array}{c}\text { Acquisition method of } \\
\text { construction land }\end{array}$} & Approved by law & 617 & $93.63 \%$ \\
\hline & $\geq 5$ & 163 & $24.73 \%$ & & Inheritance & 34 & $5.16 \%$ \\
\hline \multirow{4}{*}{$\begin{array}{l}\text { Number of family } \\
\text { labor force }\end{array}$} & 1 & 191 & $28.98 \%$ & & Purchase & 8 & $1.21 \%$ \\
\hline & 2 & 298 & $45.22 \%$ & \multirow{5}{*}{$\begin{array}{l}\text { Acquisition time of } \\
\text { construction land }\end{array}$} & $\leq 10$ years & 6 & $0.91 \%$ \\
\hline & 3 & 113 & $17.15 \%$ & & $10-20$ years & 41 & $6.22 \%$ \\
\hline & $\geq 4$ & 57 & $8.65 \%$ & & 20-30 years & 40 & $6.08 \%$ \\
\hline \multirow{4}{*}{$\begin{array}{l}\text { Annual household } \\
\text { income }\end{array}$} & $<10,000$ yuan & 41 & $6.22 \%$ & & 30 40 years & 404 & $61.31 \%$ \\
\hline & $10,000-30,000$ yuan & 88 & $13.35 \%$ & & $\geq 40$ years & 168 & $25.49 \%$ \\
\hline & $30,000-50,000$ yuan & 158 & $23.98 \%$ & \multirow{2}{*}{$\begin{array}{l}\text { Newness of residence on the } \\
\text { construction land }\end{array}$} & Renovation & 188 & $28.53 \%$ \\
\hline & $>50,000$ yuan & 372 & $56.45 \%$ & & Not renovated & 471 & $71.47 \%$ \\
\hline \multirow{2}{*}{$\begin{array}{l}\text { Willingness to } \\
\text { transfer to the city }\end{array}$} & Willing & 461 & $69.95 \%$ & \multirow{2}{*}{$\begin{array}{l}\text { Willingness of construction } \\
\text { land transformation }\end{array}$} & Willing & 253 & $38.39 \%$ \\
\hline & Unwilling & 198 & $30.05 \%$ & & Unwilling & 406 & $61.61 \%$ \\
\hline
\end{tabular}


Table 3 presents the results of descriptive statistics to predict the direction of impact on the decision-making behavior of rural construction land consolidation.

Personal characteristics were characterized by two indicators: age and education level. In theory, the farmers would be more attached to the rural construction land along with increasing age, which weakens the motivation for transformation [26]. The older the person, the lower the chance they have of working in the city, which means that the older farmer may not tend to enter the city. Thus, they would rather stay on their rural settlement without any transformation. Farmers with higher education levels were more open to new ideas and thoughts. Therefore, these farmers could better understand policies with less cognitive bias, and therefore were more likely to transform their construction land.

The variables of family characteristics included family size, size of labor force, total income, total expenditure, and quantity of cultivated land. Specifically, larger families lead to a heavier financial burden when living in the city, which means farmers would be more reluctant to transfer from rural construction land. When the number of family laborers and the total income increase, the conditions for living in the city improve, which leads to stronger transferring intention. A larger total expenditure also increases the load on the family and the difficulty of living the city for the farmers, and finally leads to a smaller transferring probability. When more cultivated land is used, more farmers tend to engage in agricultural production, and the willingness to transition construction land decreases.

The status of construction land included size of construction land, how construction land was obtained, length of ownership, and the age of the residence on the land. Firstly, the probability of idle construction land transformation increases along with the pieces of the construction land. Secondly, when the construction land was obtained through inheritance, a low transfer rate may be expected due to the existence of relative reciprocity and altruistic effects [10]. Thirdly, similar to the age variable, the longer the length of ownership of the construction land, the more attachment the farmer may have to the rural construction land. Then, this effect will weaken the transformation intention.

Compensation for construction land transformation includes compensation method, resettlement housing, and standard rationality measurement. For the compensation method, farmers who have already purchased a house in the city would prefer monetary compensation, whereas farmers who do not have a house in the city would prefer replacement of urban housing. Once farmers decide to transform their rural construction land, they can either choose to move to resettlement houses in the city or move to resettlement apartments or buildings in the same village. Local government encourages farmers to settle in the city to accelerate urbanization and collective economic development, and promote the rearrangement of rural land. For resettlement housing, farmers who do not want to enter the city are more likely to choose to maintain the original mode of residence, hoping to receive reasonable monetary compensation; whereas those who are willing to enter the city will use the urban housing as resettlement buildings. Furthermore, those who think that the government provides reasonable compensation are more inclined to transfer from their rural construction land.

Settling to the city and moving from original rural construction land should be a process of mutual promotion. The desire to settle in the city indicates settlement expectation. The willingness to settle in the city is expected to affect the willingness of rural construction land transformation. 
Table 3. Variable settings and descriptions.

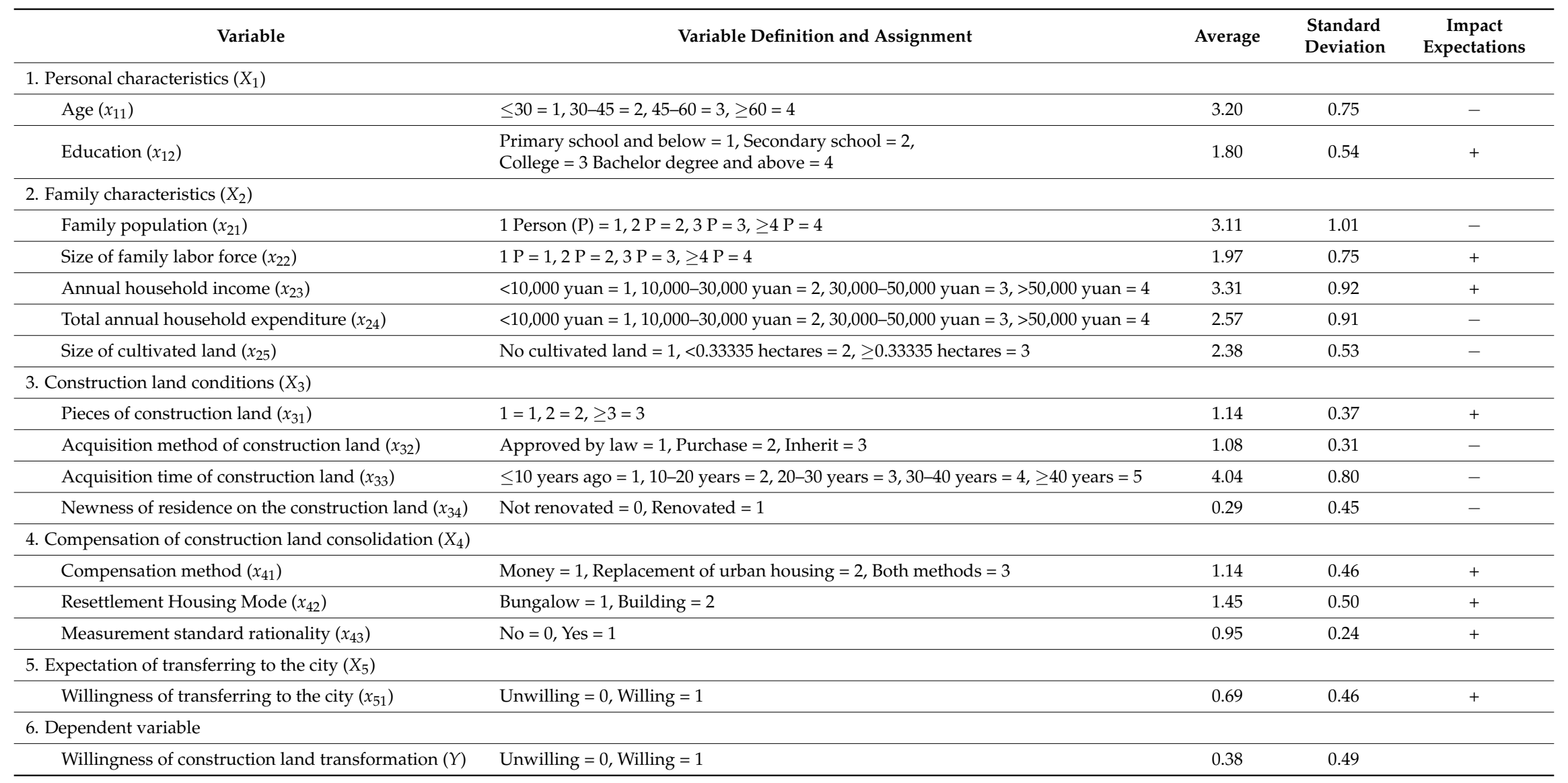




\subsubsection{Method}

There were two options for decision-makers with rural construction land: willingness and reluctance. The two options correspond to the different attributes of farmers' characteristics. They are discrete variables based on classified data that establish a binary dependent variable estimation model. The Probit model was selected as the estimation method [28]. Since the variable $Y$ is a 0,1 variable, the linear model is not suitable for direct estimation. Therefore, the latent variable $Y^{*}$ was introduced, expressed as:

$$
Y^{*}=\beta_{i} X_{i}+\varepsilon_{i}
$$

where $\beta$ is the parameter to be estimated, $X_{i}$ is an observable independent variable, and $\varepsilon$ is a random disturbance term that obeys a normal distribution.

The relationship between $Y$ and latent variable $Y^{*}$ can be expressed as:

$$
Y=0, \operatorname{IF} Y^{*} \leq 0 ; Y=1, \operatorname{IF} Y^{*}>0
$$

Given $X_{i}$, the probabilities of 0 and 1 , respectively, for $Y$ are:

$$
\begin{gathered}
\operatorname{Prob}\left(Y=0 \mid X_{i}\right)=\operatorname{Prob}\left(Y^{*} \leq 0 \mid X_{i}\right)=\operatorname{Prob}\left(\beta_{i} X_{i}+\varepsilon_{i} \leq 0 \mid X_{i}\right)=F\left(-\beta_{i} X_{i}\right) \\
\operatorname{Prob}\left(Y=1 \mid X_{i}\right)=\operatorname{Prob}\left(Y^{*}>0 \mid X_{i}\right)=1-F\left(-\beta_{i} X_{i}\right)
\end{gathered}
$$

where $F(X)$ represents the standard normal distribution function. The parameters can be measured using Maximum Likelihood Estimation (MLE).

\subsection{Data Analysis}

2.4.1. Willingness of Different Household Types to Transform Rural Construction Land to Cultivated Land

According to the different types of farmer households and the intention to transform their rural construction land, a cross-linking table was formed (Table 4).

Table 4. Different types of farmer willingness for construction land transformation.

\begin{tabular}{ccccc}
\hline \multicolumn{2}{c}{ Type of Farmer } & Number & $\begin{array}{c}\text { No. Farmers Who } \\
\text { Are Willing to } \\
\text { Transform }\end{array}$ & $\begin{array}{c}\text { Proportion of } \\
\text { Farmers Willing to } \\
\text { Transform (\%) }\end{array}$ \\
\hline Willingness to settle & Willing & 455 & 221 & 48.57 \\
in the city & Unwilling & 204 & 32 & 15.69 \\
\hline Number of & 1 & 577 & 220 & 38.13 \\
construction land & $\geq 2$ & 82 & 33 & 40.24 \\
\hline \multirow{2}{*}{ Acquisition method } & Approved by law & 616 & 254 & 41.23 \\
& Purchase & 8 & 2 & 25.00 \\
Acquisition time & Inherit & 35 & 6 & 17.14 \\
\hline Newness of residence on & Not renovated & 471 & 207 & 42.16 \\
the construction land & Renovation & 188 & 46 & 27.38 \\
\hline
\end{tabular}

Among all the respondents, 455 were willing to settle in the city, of which 211 were willing to transform their rural construction land, accounting for $48.57 \%$. Those who did not want to enter the city but were willing to transform their rural construction land accounted for $15.69 \%$. This fully explains the process of mutual promotion of farmers' willingness to settle in the city and the willingness to transform their rural construction land. There were two main reasons that encourage farmers to 
transform their idle rural construction land once they decided to settle in the city. On the one hand, after settling in the city, if farmers decide to transform their idle rural construction land, they would receive compensation from the local government. On the other hand, urban living conditions and income sources are better than available in rural life, so that they may not relocate after settling in the city.

Among the 82 rural households with two or more pieces of construction land, 33 were willing to transform their rural construction land, accounting for $40.24 \%$, and households with one piece of rural construction land accounted for $38.13 \%$. This indicates that there were many areas with idle rural construction land. The willingness of farmers with multiple pieces of idle construction land are more willing to transform, and the focus of rural construction land consolidation management practice should include idle rural construction lands.

In terms of rural construction land acquisition method, $41.23 \%, 25 \%$, and $17.14 \%$ of the farmers approved, purchased, and inherited their rural construction land, respectively, were willing to transform. Compared with the those who obtained construction land by law or purchasing, those who obtained rural construction land via inheritance were the most reluctant to transform their rural construction land.

When the construction land was owned for more than 40 years, $27.38 \%$ of farmers were willing to transform, with an obviously lower proportion than farmers who owned the construction land for less than 40 years. Moreover, $42.68 \%$ of the farmers who did not renovate their residence on the construction land were willing to make the transformation, which was significantly higher than those who renovated their residences on the construction land.

In general, households that were willing to settle in the city had multiple pieces of rural construction land, legally approved or purchased their construction land, had owned the construction land for a short time, and had not renovated the residence, were relatively more inclined to make the transformation.

\subsubsection{Factors Influencing Decision-Making for Rural Construction Land Transformation}

Based on the self-correlation test for independent variables, Probit analysis was conducted by using Stata 14.0 (Figure 3). Factors affecting the decision-making behavior to transform the rural construction land, and the willingness to settle in the city were measured, respectively. The logistic regression (LR) statistics of the two models were all significant at the $1 \%$ confidence level, resulting in a good fit for the model [38].

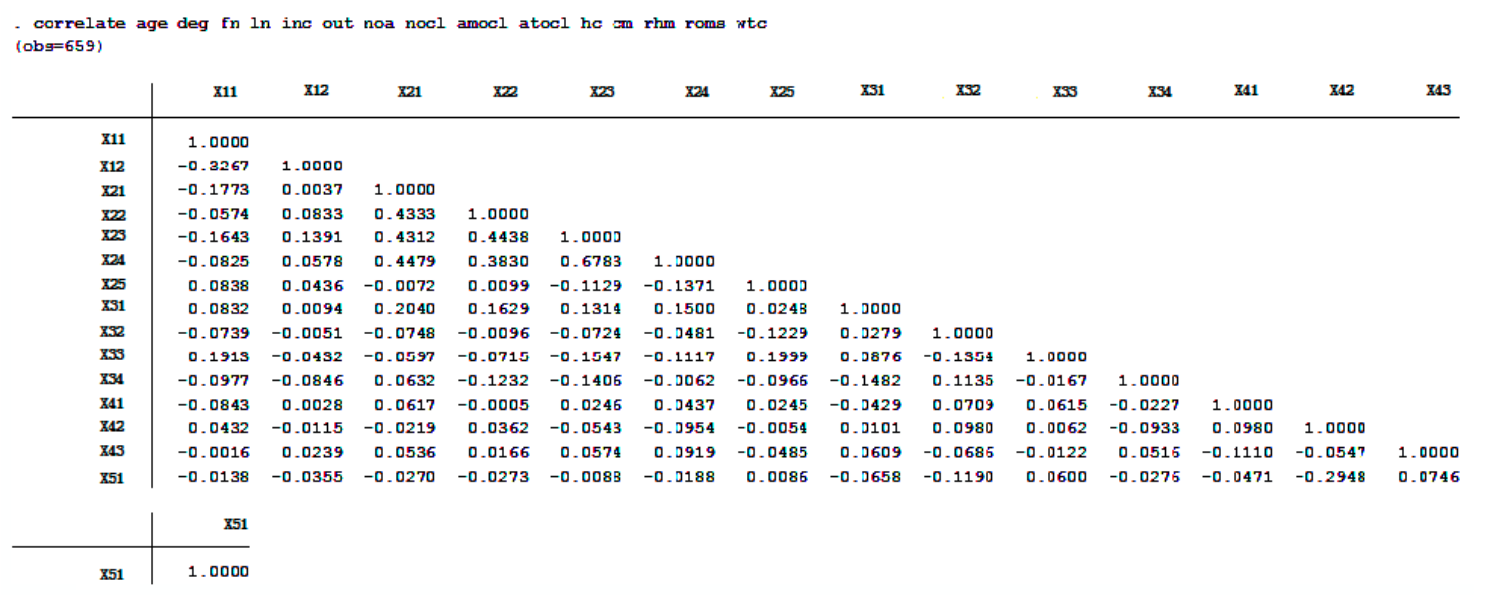

Figure 3. Variable autocorrelation test.

Based on the estimated results from all the samples, the factors that positively affected the willingness of transforming rural construction lands included the willingness to transfer to the city, compensation method, the method of resettlement, the rationality of measurement standards, and 
total annual household income. The factors that negatively affected the willingness to transform rural construction land included the age of the residence on rural construction land, family size, acquisition method, and amount of cultivated land.

The willingness to settle in the city positively affected the decision-making on rural construction land transformation, further demonstrating the mutual promotion between settlement in cities and the transformation of rural construction land. Specifically, among the sample of residents who wished to settle in the city, the factors that significantly affected the decision-making behavior of farmers' rural construction land transformation included the mode of resettlement, the number of family members, the compensation method, the owners duration of the construction land, the annual total household expenditure, and the amount of cultivated land. Compared with the entire sample, the estimation results were basically the same, and some indicators were slightly different (Table 5).

Table 5. Model estimation results.

\begin{tabular}{|c|c|c|}
\hline \multirow[b]{2}{*}{ Independent Variables } & \multicolumn{2}{|c|}{ Estimated Coefficient } \\
\hline & Total Samples & $\begin{array}{l}\text { Sample for People Who Are } \\
\text { Willing to Settle in the City }\end{array}$ \\
\hline Total numbers & 659 & 455 \\
\hline LR $X^{2}(15)(14)$ & 140.11 & 69.92 \\
\hline Prob $>X^{2}$ & 0.00 & 0.00 \\
\hline $\begin{array}{c}\text { Pseudo } R^{2} \\
X_{1}\end{array}$ & 0.16 & 0.11 \\
\hline$x_{11}$ & -0.01 & 0.04 \\
\hline $\begin{array}{l}x_{12} \\
X_{2}\end{array}$ & 0.01 & -0.02 \\
\hline$x_{21}$ & $-0.19^{* * *}$ & $-0.24^{* * *}$ \\
\hline$x_{22}$ & 0.11 & 0.11 \\
\hline$x_{23}$ & $0.15^{*}$ & 0.15 \\
\hline$x_{24}$ & 0.09 & $0.20 * *$ \\
\hline $\begin{array}{l}x_{25} \\
X_{3}\end{array}$ & $-0.20 *$ & -0.24 * \\
\hline$x_{31}$ & 0.08 & 0.16 \\
\hline$x_{32}$ & $-0.42 *$ & -0.29 \\
\hline$x_{33}$ & -0.09 & $-0.22 * * *$ \\
\hline $\begin{array}{l}x_{34} \\
X_{4}\end{array}$ & $-0.40^{* * *}$ & $-0.34^{* *}$ \\
\hline$x_{41}$ & $0.39^{* *}$ & $0.46^{* * *}$ \\
\hline$x_{42}$ & $0.35^{* * *}$ & $0.35^{* * *}$ \\
\hline$x_{43}$ & $0.44 *$ & 0.39 \\
\hline$X_{5}$ & & - \\
\hline$x_{51}$ & $0.93^{* * *}$ & - \\
\hline
\end{tabular}

\section{Results}

The two factors, resettlement housing mode and compensation method, most significantly impacted the decision-making of farmers' rural construction land transformation, which shows that the primary consideration of farmers in the transformation process of rural construction land is the guarantee of livelihood capital after they transform their rural construction land.

From the point of view of the resettlement housing model, if housing can be replaced with a set of buildings, it will effectively solve the problem of insufficient livelihood capital and poor living environment after the farmers retire, thus increasing the enthusiasm of the farmers for land transformation. The compensation method of resettlement housing is more influential to the people who are willing to settle in the city. This shows that "retreat" is a factor that must be considered for rural households to transform their rural construction land or for the government to implement the rural construction land consolidation policy. To replace the housing conditions for the farmers, resettlement 
housing eliminates the cost of house purchase, effectively alleviating the economic pressure due to urban life [21]. The reasonableness of the measurement standard had a positive effect on the farmers' decision-making behavior for rural construction land transformation, but did not have a significant impact on the farmers' willingness to settle in the city. This may be because the willingness to settle in the city reduces the subjective judgment of the rationality of the compensation measurement standard.

Secondly, from the perspective of residence condition, the age of the residence on the rural construction land had a significant negative impact on the decision-making behavior of farmers' rural construction land transformation. According to statistics, among all the samples, the percentage of farmers who owned refurbished houses that agreed to transform rural construction land was $27.66 \%$, and the percentage of farmers who owned non-refurbished households who agreed to the transformation was $42.68 \%$. Short interviews were conducted with farmers during the survey. Through interviews with farmers, they claimed that the cost of decorating a house is generally around 100,000 yuan. If a house is refurbished, the total cost of the residence would be between 15 and 25 million yuan. Households need certain capital investment for refurbishing or rebuilding. In the process of rural construction land transformation decision-making behavior, farmers perform a cost-benefit analysis. When they transform the refurbished residence and settle in city, they have psychological awareness of "not worth the bullets", which negatively affects their decision-making behavior.

Due to the endowment effect, land ownership duration had a significant negative impact on the willingness to transform rural households to cities. The proportion of rural construction land owner duration of over 30 years was $86.80 \%$. The age of the respondents was relatively old, so although there was some willingness to settle in the city, these land owners may not choose to transform their rural construction land.

Obtaining rural construction land through inheritance negatively impacted the willingness of rural construction land transformation from all samples, but the effect on households who wished to settle in the city was not significant. Since the rural construction land inheritance system symbolizes ties of kinship, farmers with inherited land tended to not make the transformation due to familial attachment. However, the willingness to live in cities may subjectively weaken the attachment.

The number of family members had a significantly negative effect on the decision-making of rural construction land transformation, which reflects the pressure that family structural factors have during the decision-making process. This may due to the fact that the concept of family is important to farmers, and the uncertainty of life in the city makes the farmers unwilling to change their current situation. Previous studies showed that the status quo of farmers and the uncertainty of the future state negatively affect rural construction land transformation [26,39].

The amount of cultivated land had a significantly negative impact on the willingness of rural households to transform from their rural construction land. According to the statistics, among the farmers without cultivated land, $60 \%$ intended to transform rural construction lands, and $90 \%$ were willing to transfer to households to the city. The reason may be because the greater the cultivated land owned, the higher the proportion of crop income in total household income. Therefore, after transforming the rural construction land and settling into the city, the structure of the family income changes, and the stable income source for farmers is lost for a period of time. Moreover, farmers are accustomed to traditional cultivated habits, which would decrease the willingness of farmers to transition from their rural construction land.

The total household annual expenditure had no significant effect on the willingness of all rural households to transform from their rural construction land, but it positively impacted the decision-making behavior of farmers who were willing to settle in the city, which is inconsistent with the expected results. Considering the variability in family annual total income, the average annual household income of farmers who were willing to enter the city was considerably higher than the average income level. In pursuit of quality of life, farmers' willingness to transform rural construction land and settle in the city would be more intense. 
The total household income had a significant impact on the willingness of all households to transform from rural construction land, but the impact on farmers' willingness to settle in the city was not significant. The reason may be that the strong willingness to settle in the city weakened the excessive assessment and consideration of the household income.

\section{Discussion}

Among the factors that affect the decision-making behavior of rural construction land transformation, the willingness to settle in the city, the mode of housing resettlement, the mode of compensation, the rationality of the measurement standards, and the annual total household income had positive effects. The measurement results of the mode of housing resettlement, the mode of compensation, the rationality of the measurement standards and the annual total household income was consistent with previous researches [26,30,32,34]. Huang and Zhong [39] presented that the mode of compensation did not affect farmers' decision-making behavior, which is different from the results of this study. This is probably due to economic determinants. The research of Huang and Zhang [39] was conducted in villages with convenient transportation and well-developed collective economy, where farmers could gain economic benefit from their collective economy. Hence, farmers from villages that are fairly developed economically tend not to attracted by transformation compensation if the compensation is lower than the income from the collective economy. Therefore, the key point for local governments in guiding farmers to transform their rural construction land should be considering proper rural construction land compensation. Moreover, since households with high income have strong desire to transform their rural construction land and settle in the city, local government could focus on provide urban resettlement houses to encourage their transformation behavior [28,30].

The age of the residence, family size, the method of obtaining rural construction land, and the amount of cultivated land negatively affected the decision-making behavior. The measurement result of obtaining rural construction land through inheritance remained consistent with previous research [30]. This indicated that farmers tend not to transform their rural construction land if it was inherited from their elder generation. Among the farmers who were willing to settle in the city, the rationality of the measurement standard and the method of rural construction land acquisition were not significant. This indicates that the willingness to settle in the city weakens the subjective consideration or discrimination of other factors.

The variables of age and pieces of construction land was proved positively affected farmers' transformation decision-making behavior in previous researches $[19,28,40]$. While in this study, the influence of these variables on farmers' transformation decision-making behavior was not significant. On the one hand, since most households in the sample only had one piece of rural construction land, the impact of multiple construction lands on the transformation behavior may not reveal significant. On the other hand, among the villages analyzed in previous researches, agriculture was no longer the main source of household income, and most young people tended to go to work in cities. When farmers grew old, they were willing to move to the city and lived with their children, so that the rural construction land could be transformed [19,28]. However, in this study, agriculture, rural businesses and tourism services were the main sources of household income in the four villages. Youngsters preferred to stay in their village to help their parents. Therefore, the factor of age may not be an influencing factor of farmers' transformation behavior in this study.

Based on the above analysis results, considering the feasibility of the implementation of rural construction land consolidation policies, relevant policy recommendations can be provided. According to individual characteristics and family environment factors, the government could guide rural construction land transformation in batches and explore suitable compensation methods for farmers with different features. Firstly, since the willingness to settle in the city positively influences the decision-making behavior of farmers to transform their rural construction land, the local government should pay more attention to the farmers who intend to settle in the city, as this group of people is more inclined to transform their rural construction land at the psychological consciousness level. 
If farmers in this group already have urban residences, monetary compensation could be offered to them. If farmers in this group do not have urban residences, resettlement housing compensation could be offered so that they move to the city without worrying about housing. Secondly, according to the statistics, of the 659 households, there were 82 pieces of rural construction land that were idle, accounting for $12.44 \%$ of the total land area. The transformation willingness accounted for $40.24 \%$, which is slightly higher than the overall level. This indicates that, to achieve rural construction land consolidation, unused rural construction land should be transformed. Local government could provide farmers a corresponding monetary compensation amount based on market price. Thirdly, the local government should also focus on the relatively rich living conditions of farmers. Their pursuit of quality of life and their own development will encourage them to settle in the city. Therefore, the focus of policy formulation should be the provision of reasonable economic compensation. Lastly, small families, those with limited cultivated land, and those with old houses should be paid particular attention. These groups experience a lesser financial burden in moving, and the income from cultivated is relatively low, which leads to a lower cost of rural construction land transformation. Therefore, the key point of policy formulation is to provide residence and reasonable compensation for this group of people.

This survey has some limitations. This study did not include the situation of the illegal occupation of rural construction land. It was difficult to collect data because of the household survey. However, from the actual situation, this situation does exist. For the over standard illegal rural construction land, the local government can benefit from the principle of "delimiting grade pricing and exceeding the charge" that was implemented in Shandong province [41]. Through the establishment of a constraint mechanism, local government may gradually guide farmers to transform rural construction land. The government should also provide appropriate economic compensation to farmers who have voluntarily transformed their excess land.

Since the research provided limited data for some areas of Jizhou District, the research results only reflect the decision-making behavior of rural households in the survey area. Future research needs to supplement the data with data from more regions in order to improve the scientific research.

\section{Conclusions}

Rural construction land transformation and land rearrangement are long-term, dynamic, and sustainable processes. Effective rural construction land transformation contributes to the expansion of cultivated land and ensures food security and sustainable development. A household survey was conducted in four typical villages in Jizhou District in Tianjin, China. After data collection, the Probit model was applied to study the decision-making behavior and factors influencing farmers' rural construction land transformation. The results indicated that there are two main kinds of compensation that appear to be more attractive to farmers to transform their rural construction land: monetary compensation and resettlement housing. The measurement results of variables, such as annual total income, the method of obtaining rural construction land, the rationality of the measurement standards, and the mode of housing resettlement, was consistent with previous studies [26,30]. A new factor-the willingness to settle in the city—was also measured, which positively influenced farmer's decision-making behavior in terms of rural construction land transformation. Therefore, it is necessary for local governments to formulate construction land consolidation policies in targeted areas.

Author Contributions: All authors contributed equally to this work. Specifically, X.S. developed the original idea for the study and designed the methodology. Y.Z. completed in the survey and drafted the manuscript, which was revised by Z.Z. All authors read and approved the final manuscript.

Funding: This research was funded by the National Social Science Foundation of China, Research on the Generating Mechanism Evaluation Method and Governance Model of the Political Cost of Environmental Pollution Problem, [16BGL138].

Conflicts of Interest: The authors declare no conflict of interest. 


\section{References}

1. Fang, Y.; Shi, K.; Niu, C. A comparison of the means and ends of rural construction land consolidation: Case studies of villagers' attitudes and behaviours in Changchun City, Jilin province, China. J. Rural Stud. 2016, 47, 459-473. [CrossRef]

2. Wang, Q.; Zhang, X.; Wu, Y.; Skitmore, M. Collective land system in China: Congenital flaw or acquired irrational weakness? Habitat Int. 2015, 50, 226-233. [CrossRef]

3. Ma, J.G.; Tang, M.Y. Thoughts and methods of reforming and perfecting the rural homestead system. Huabei Land Resour. 2015, 5, 73-74. (In Chinese)

4. Yang, Y.; Xie, J.; Jiang, G. On the evolution, problems and ways to reform of management system of rural residential land in China. Sci. Technol. Manag. Land Resour. 2017, 34, 65-72.

5. Long, H.; Li, Y.; Liu, Y.; Woods, M.; Zou, J. Accelerated restructuring in rural China fueled by 'increasing vs. decreasing balance' land-use policy for dealing with hollowed villages. Land Use Policy 2012, 29, 11-22. [CrossRef]

6. Liu, Z.; Müller, M.; Rommel, J.; Feng, S. Community-based agricultural land consolidation and local elites: Survey evidence from China. J. Rural Stud. 2016, 47, 449-458. [CrossRef]

7. Ho, P. Myths of tenure security and titling: Endogenous, institutional change in China's development. Land Use Policy 2015, 47, 352-364. [CrossRef]

8. Jiang, G.; He, X.; Qu, Y.; Zhang, R.; Meng, Y. Functional evolution of rural housing land: A comparative analysis across four typical areas representing different stages of industrialization in China. Land Use Policy 2016, 57, 645-654. [CrossRef]

9. Fang, Y.; Liu, J. The modification of North China quadrangles in response to rural social and economic changes in agricultural villages: 1970-2010s. Land Use Policy 2014, 39, 266-280.

10. Yang, Y. Theoretical analysis of farmers' behavior decision in the retirement of Homestead. J. Agrotech. Econ. 2014, 4, 53. (In Chinese)

11. Zhang, L.; Du, H.; Zhao, Y. Game Behavior Analysis between the Local Government and Land-Lost Peasants in the Urbanization Process. Sustainability 2016, 8, 1213. [CrossRef]

12. Jiang, X.S.; Liu, S.Y.; Li, C. Land System Reform in China: Policy Evolution and Local Implementation; Shanghai Sanlian Press: Shanghai, China, 2010; Volume 7, pp. 306-312. (In Chinese)

13. He, X. Prudently and steadily promoting the reform and improvement of rural homestead management system. Chin. Cadres Trib. 2014, 6, 18-20. (In Chinese)

14. Lin, C.; Tan, J. Research on the reform of rural homestead system based on the analysis of the evolution of homestead function. Reform Econ. Syst. 2013, 5, 69-72.

15. Liu, S. The most important thing to break through is the homestead system. Development 2013, $10,31$. (In Chinese)

16. Zhang, D. Some thoughts on the reform of rural homestead system. Land Resour. Her. 2012, 2, 44-46. (In Chinese)

17. Zhang, Q.F.; Wu, J. Political Dynamics in Land Commodification: Commodifying Rural Land Development Rights in Chengdu, China. Geoforum 2017, 78, 98-109. (In Chinese) [CrossRef]

18. Chen, C. Chongqing Land Ticket: System Innovation and Protection of Farmers' Rights and Interests. Master's Thesis, Southwest University of Political Science and Law, Chongqing, China, 2015. (In Chinese)

19. Wang, Z.; Yang, Q.; Wang, N. Study on the protection of farmers' land income in the withdrawal of Chongqing Homestead: From the perspective of comparative income. China Land Sci. 2016, 8, 47-55. (In Chinese)

20. $\mathrm{Xv}, \mathrm{Z}$. Investigation and analysis of farmers' willingness to quit their homestead in Jiaxing, Zhejiang. Land Resour. Shanghai 2013, 34, 29-33. (In Chinese)

21. Lu, Y.X.; Hu, Y.Y.; Lin, J.H.; Dai, Y.Y. Investigation and Reflection on the pattern of Zhejiang farmers' homestead exit. China Land Sci. 2011, 25, 3-7. (In Chinese)

22. Li, Y.; Wang, Q. Theoretical hypothesis and empirical test on the exit mode of Rural Homestead: A case study of Chengdu and Suzhou. Rural Econ. Sci.-Technol. 2016, 27, 17-19. (In Chinese)

23. Simon, H.A. Theories of bounded rationality. In Decision and Organization: A Volume in Honor of Jacob Marschak; North-Holland Publishing Company: Amsterdam, The Netherlands, 1972; Volume 1, pp. 161-176.

24. Yang, Y. Why are farmers reluctant to make a paid withdrawal of homestead. Economist 2015, 5, 68-77. (In Chinese) 
25. Wang, Z.; Yang, Q.; Zhang, B. Analysis of farmers' willingness to land withdrawal and its influencing factors in the reform of household registration system. Chin. Rural Econ. 2011, 11, 49-61. (In Chinese)

26. Yang, Y. Influencing factors and policy convergence of peasant households' idle housing land withdrawal—A behavioral economics perspective. Econ. Geogr. 2015, 7, 140-147. (In Chinese)

27. Wang, H.; Wang, L.; Su, F.; Tao, R. Rural residential properties in China: Land use patterns, efficiency and prospects for reform. Habitat Int. 2012, 36, 201-209. [CrossRef]

28. Chen, $X$. Factors affecting the willingness to withdraw from farmers' Homestead-An Empirical Analysis Based on 1012 households in the two wings of Chongqing. China Rural Surv. 2012, 3, 26-36. (In Chinese)

29. Tong, Y.; Niu, H.; Fan, L. Willingness of Farmers to Transform Vacant Rural Residential Land into Cultivated Land in a Major Grain-Producing Area of Central China. Sustainability 2016, 8, 1192. [CrossRef]

30. Zhang, Y.; Qiu, D.; Li, Y. Analysis of the influencing factors of migrant workers settling in cities and housing land withdrawal-Based on a questionnaire survey of 357 migrant workers in Kaixian, Chongqing. China Soft Sci. 2011, 2, 62-68. (In Chinese)

31. Peng, X. Improvement of rural homestead withdrawal mechanism from the perspective of farmers' rights and interests protection. Rural Econ. 2015, 4, 9-13.

32. Yu, W.; Liu, B.; Song, J. Decision making behavior and influencing factors of farmers' homestead withdrawal in the process of Urbanization. Geogr. Res. 2016, 3, 551-560. (In Chinese)

33. Xu, H.; Wu, G.; Guo, Y. Analysis of the impact of homestead ownership on migrant workers' willingness to quit in different generations-An Empirical Study Based on 248 questionnaires in Tianjin. Resour. Sci. 2013, 7, 1423-1429. (In Chinese)

34. Zhu, X. The influence of household registration system on the willingness of farmers to withdraw their homestead. China Popul. Resour. Environ. 2014, 10, 129-134. (In Chinese)

35. Ouyang, A.; Cai, F.; Cheng, L. Discussion on the establishment of rural homestead withdrawal mechanism. China Land Sci. 2009, 10, 26-30. (In Chinese)

36. Cheng, X.; Jiang, X. Residential land use right system: Normative analysis, practical challenges and legislative response. Manag. World 2010, 10, 1-12. (In Chinese)

37. Han, C. There are three major contradictions in the homestead system. People's Trib. 2008, 14, 38-39. (In Chinese)

38. DeVellis, R.F. Scale Development: Theory and Applications, 2nd ed.; Sag Publications: Thousand Oaks, CA, USA, 2003; pp. 27-57, ISBN 0-7619-2604-6.

39. Huang, Y.; Zhong, Z. Response of different types of farmers to the withdrawal of Homestead. Resour. Environ. Yangtze Basin 2013, 7, 852-857. (In Chinese)

40. Huang, Y. Analysis on the influencing factors of farmers' participation in the withdrawal of Homestead-Taking Liangping County of Chongqing as an example. J. Huazhong Agric. Univ. (So. Sci. Ed.) 2013, 3, 36-41. (In Chinese)

41. Wang, Q.; Wang, A.; Dongye, G.; Shi, L. Study on technology mode of rural residential land consolidation-Taking Huji town of Huinin county as an example. J. Shandong Agric. Univ. 2009, 40, 550-554. (In Chinese)

(C) 2018 by the authors. Licensee MDPI, Basel, Switzerland. This article is an open access article distributed under the terms and conditions of the Creative Commons Attribution (CC BY) license (http://creativecommons.org/licenses/by/4.0/). 